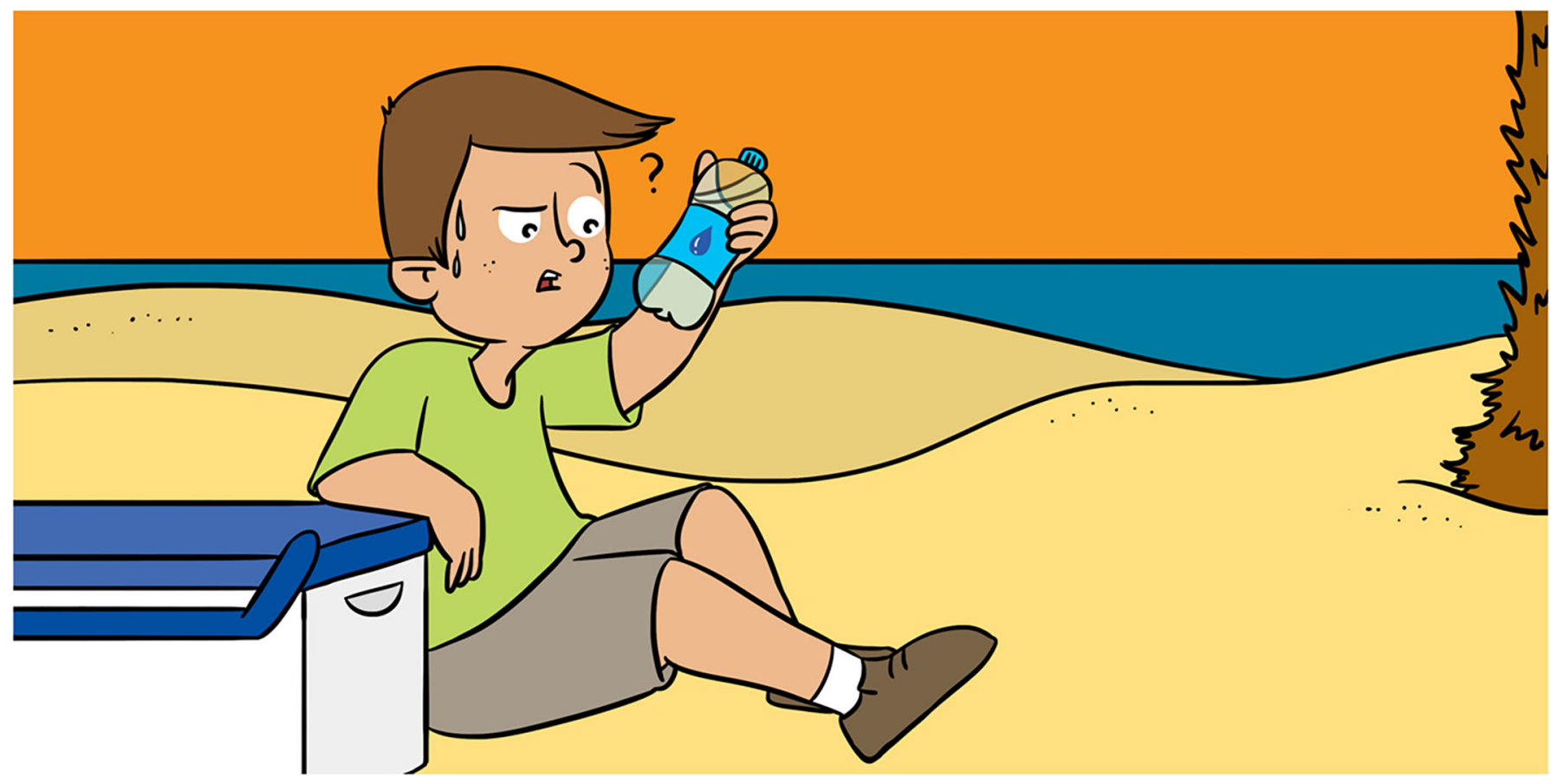

\title{
BACTERIA AND CHEMICALS IN MY BOTTLED WATER?!
}

\section{Helena de Oliveira Souza ${ }^{1 *}$, Gabrielle Rabelo Quadra ${ }^{2 t}$, Rafaela dos Santos Costa ${ }^{3}$, Emília Marques Brovini ${ }^{4}$, Jéssica Andrade Vilas-Boas ${ }^{2}$ and Marcos Antonio Fernandez ${ }^{1}$}

${ }^{1}$ Universidade do Estado do Rio de Janeiro, Programa de Pós-Graduação em Meio Ambiente, Laboratório de Ecotoxicologia Marinha, Rio de Janeiro, Brazil

${ }^{2}$ Universidade Federal de Juiz de Fora, Programa de Pós-Graduação em Biodiversidade e Conservação da Natureza, Juiz de Fora, Brazil

${ }^{3}$ Universidade Federal do Rio Grande do Norte, Programa de Pós-Graduação em Desenvolvimento e Meio Ambiente, Natal, Brazil

${ }^{4}$ Universidade Federal de Ouro Preto, Programa de Pós-Graduação em Engenharia Ambiental, Ouro Preto, Brazil

\section{YOUNG REVIEWER:}

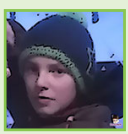

FIN

AGE: 13
As sale of bottled water has grown worldwide, the reuse of plastic bottles has also increased. Reusing plastic bottles is necessary to reduce plastic pollution. However, there are chemicals in the plastic that may end up in the bottled water. It is also possible to find bacteria in bottled water! These are only two of the problems plastic bottles can cause! They are also dangerous for the environment. If you want to better understand the issues with plastic water bottles and how to help prevent them, keep reading!

It is a hot summer day, you just had fun playing outside, and now you are sweaty and exhausted. There is nothing in the world that you want more than a beautiful, shiny bottle of water. "Gulp, gulp, gulp." As the refreshing water goes down your throat, you feel completely relieved 
BIOLOGICAL

CONTAMINATION

Presence of microorganisms that may harm us or the environment.

\section{CHEMICAL}

CONTAMINATION

Chemicals that may harm us or the environment.

\section{ENDOCRINE}

\section{DISRUPTOR}

Substances that may disturb the endocrine system functioning.

\section{Figure 1}

Bottled water can be rejected because of biological

contamination, which means a higher amount of bacteria than regulations allow [1-5]. Some countries have very high rejection rates. Image was developed by Canva platform. and happy! However, water does much more than just quench your thirst. In addition to keeping you hydrated, water is responsible for regulating your body temperature and keeping your body functioning properly. Water is an essential substance for survival and health. Our bodies are made up of $20 \%$ water! But have you ever thought that the water you drink may be contaminated with something that can harm your health? Something invisible and tasteless, and that you might not even realize is there? So, before quenching your thirst, take a few minutes to read this article!

\section{BIOLOGICAL CONTAMINATION IN BOTTLED WATER}

One factor that may make bottled water unsafe for drinking is biological contamination. Biological contamination means the presence of tiny organisms such as bacteria, which can harm people or the environment. Biological contamination may result from contaminated water sources or inadequate water treatment.

Each country has its own rules regulating water quality, and these rules vary widely. Despite water quality rules, tests have found bacteria above the allowed amounts in the bottled water of several countries! When bottled water fails quality testing, it is rejected and cannot be sold. Figure 1 shows the results of water quality testing in several countries. In some countries, like Lebanon and Ghana, most bottled water is rejected because of biological contamination.

\section{CHEMICAL CONTAMINATION IN BOTTLED WATER}

We say that chemical contamination occurs when water contains chemicals that can harm us or the environment. Many chemical contaminants can be found in drinking water [6]. In this article, we will focus on a specific group of contaminants called endocrine disruptors.

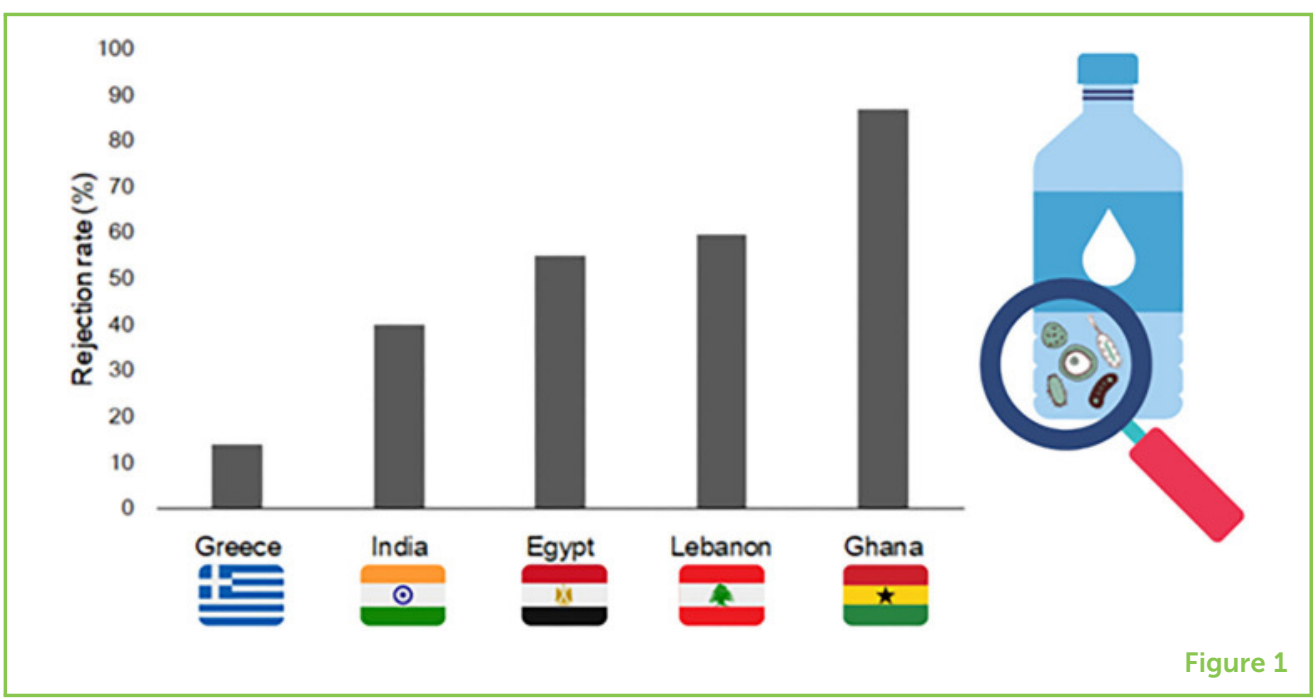




\section{ENDOCRINE}

\section{SYSTEM}

The system responsible for producing hormones.

\section{HORMONES}

The substances that are responsible for coordinating functions in the human body, such as development and survival.

\section{BISPHENOL A}

A substance used in the manufacture of plastic-based products such as bottles, toys, containers, and medical/dental products.

\section{PHTHALATE}

A substance used in many plastic products that helps to make the plastic flexible.

1 If you want to know more about these chemicals, check out $[7,8]$.

\section{REPRODUCTIVE}

\section{SYSTEM}

The system responsible for reproduction, i.e., produce new generations.

\section{Figure 2}

Endocrine disruptors like bisphenol $\mathrm{A}$ and phthalates can be released from plastic bottles into the water in response to extreme temperatures $(1,2)$. When we drink water contaminated with these chemicals (3), they may affect the endocrine system (4), because they look like our natural hormones. When they bind to our cells (5), like the cells of the reproductive system, these chemicals can cause abnormal responses. Image was developed by Canva platform.
To understand why endocrine disrupters are so dangerous, you must first understand what the endocrine system is. The endocrine system is important for coordinating the functioning of the entire body. The organs of the endocrine system produce various hormones, which are important substances that act as messengers, traveling through the body to activate various cells. Each hormone has a different function: one will make you grow, another will make you sleep, and others are responsible for reproduction, just to name a few. Every disorder of the endocrine system is called endocrine disruption. The plastic materials that water bottles are made of include some chemicals that may cause endocrine disruption. These chemicals include bisphenol A and phthalates. These chemicals can leach out of the plastic bottles into the water we drink! This occurs most often when bottled water is exposed to very low or high temperatures or when the water has been in the bottles for a long time [6] (Figure 2). Bisphenol A and phthalates have been found in drinking water worldwide ${ }^{1}$.

\section{HOW DO BISPHENOL A AND PHTALATES AFFECT THE ENDOCRINE SYSTEM?}

To the cells of the body, bisphenol A and phthalates look quite similar to the natural hormones of the reproductive system, so these chemicals can confuse our cells when they are present in high concentrations. For example, when the cells of the reproductive system bind to these chemicals, the chemicals generate abnormal responses in the cells and can even stimulate the growth of cancer cells (Figure 2). The effects of some endocrine disrupters have been shown in laboratory rats, which have the system pretty similar to ours, but the effects of these endocrine disrupters in humans remain uncertain and still being studied [9].

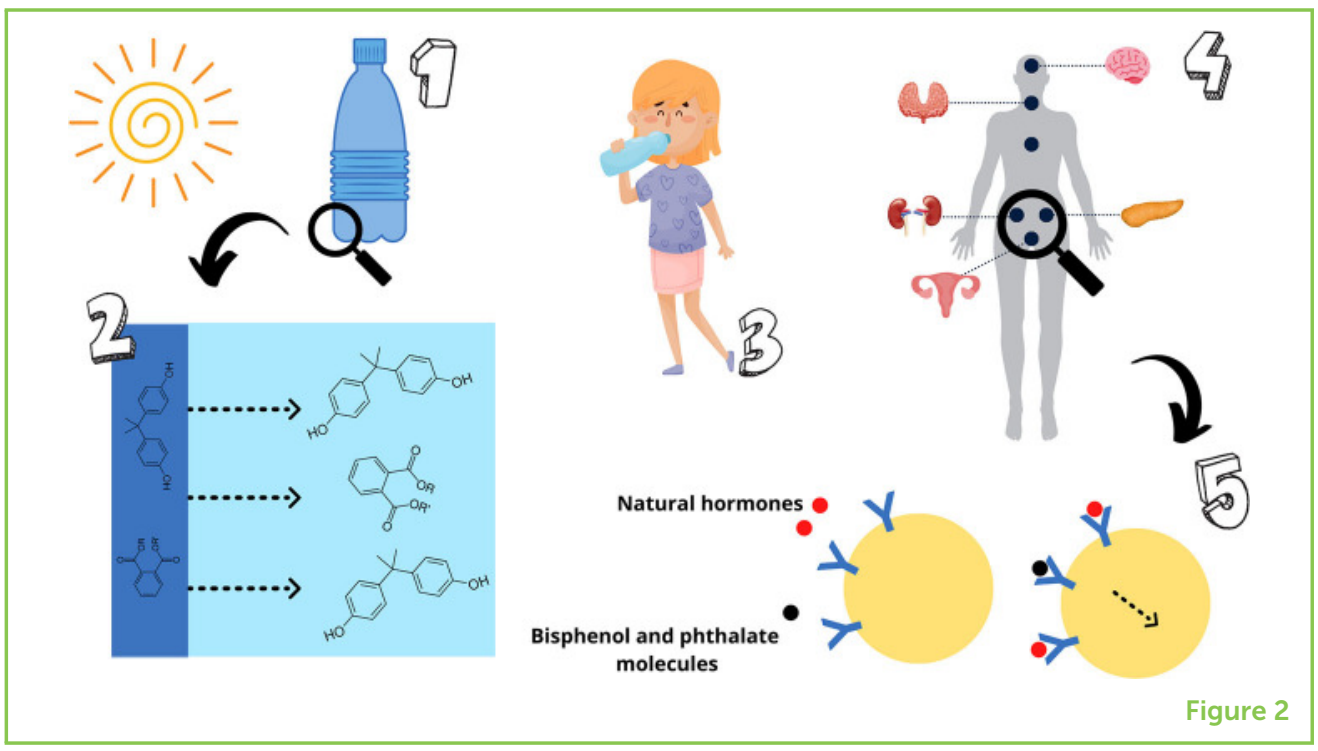


Many chemicals in bottled water do not cause these negative effects immediately, because they are only present in low concentrations in the water. But the problem is that some of these chemicals may stick around in our bodies for a long time. As we continue to drink bottled water with chemical contamination, endocrine disrupters may build up in our bodies and eventually affect the endocrine system.

\section{THE GLOBAL BOTTLED WATER PROBLEM: WHAT SHOULD WE DO?}

Who does not want to drink a good bottle of water? Most people believe that bottled water is some of the safest water to drink. It is also very practical! However, more and more research is showing that bottled water might cause problems both for humans, as you have just learned, and for the environment (Figure 3). So, what can we do to keep ourselves and the environment safe?

First, protect your own health! Try to use glass or metal bottles instead of plastic, when possible. This will help to reduce plastic pollution, too! If you are using plastic water bottles, try to find some that are bisphenol free. When reusing plastic water bottles, make sure they do not have cracks that may give bacteria places to grow. Last, make sure your bottled water is not exposed to extreme temperature changes.

Figure 3

Ways to protect ourselves from the chemical and biological hazards of bottled water. Image was developed by Canva platform.

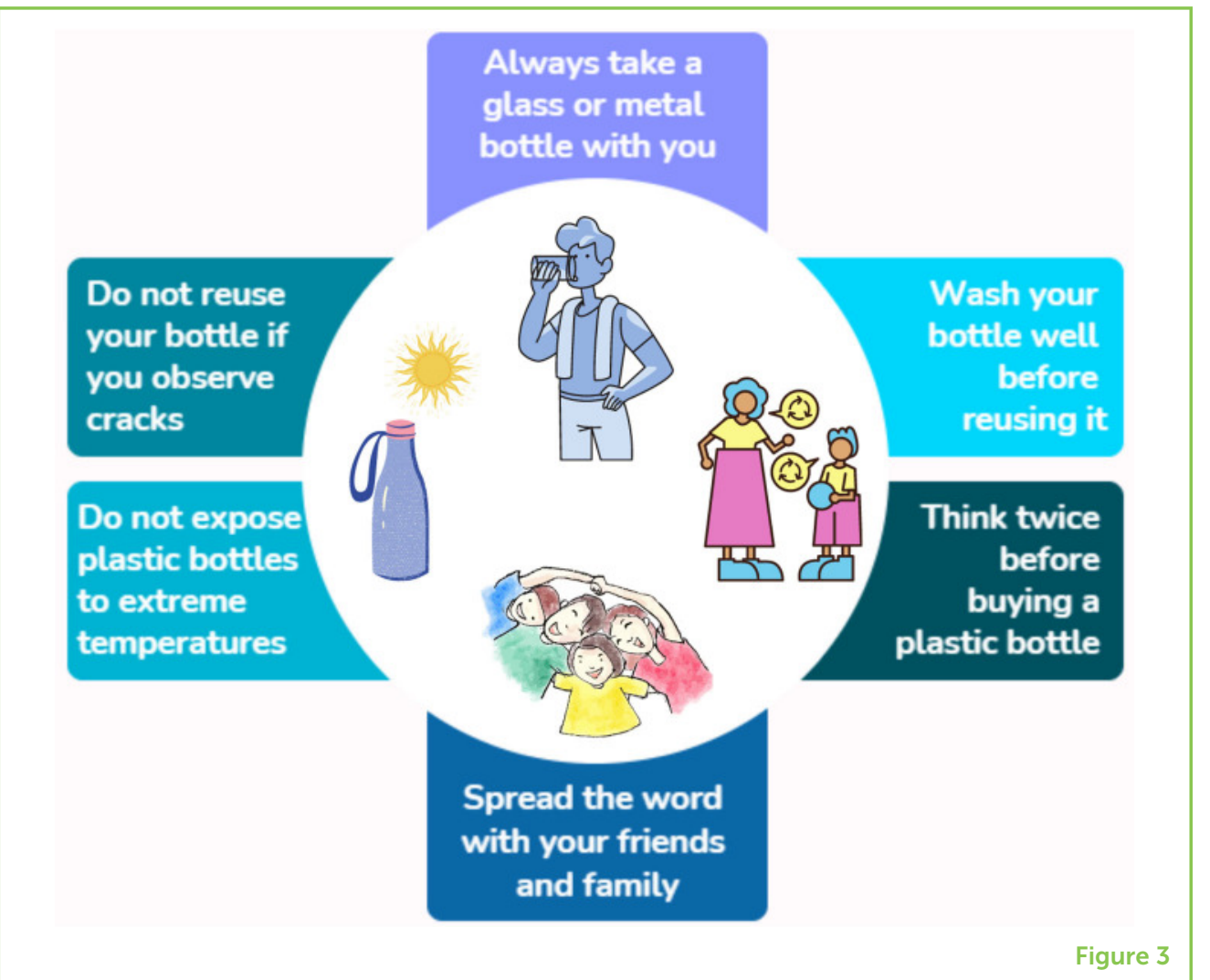


Freezing the bottles or leaving them in a hot car or exposed to sunlight can cause the chemicals in the plastic to leach into the water.

In terms of the environment, use of bottled water may cause pollution from plastics and microplastics (tiny pieces of plastic that come off bottles as they break down). Plastic bottles are recyclable, but recycling requires a lot of effort and energy, and unfortunately the process is not very fast or efficient. Plastic pollution is a global issue that affects both wildlife and human health [6, 10]. Bisphenol A and phthalates are also found in other plastic-based products, such as toys, baby bottles, paints, and food packaging. Because these chemicals may be harmful, some countries ban them from plastic products [8].

Changing our manufacturing processes and making better choices about what we use, eat, and drink will help to protect humans and the environment from endocrine disrupters and the hundreds of other potentially dangerous chemicals that we currently use. The European Green Deal, for example, aims to reduce carbon emissions and chemical use. Maybe someday this treaty will be extended across the whole world! It is a good choice to reevaluate our habits-both those involving our use of bottled water and our overall ways of manufacturing many plastic-containing products. Sharing this knowledge with our family and friends is essential. Together, by small steps, we may improve human and environmental health.

\section{ACKNOWLEDGMENTS}

This study was supported by Coordenação de Aperfeiçoamento de Pessoal de Nível Superior, Brasil (CAPES) - finance Code 001 - and Departamento de Inovação da Universidade do Estado do Rio de Janeiro (inovUERJ). We are thankful for the suggestions and support of the young reviewer Fin.

\section{REFERENCES}

1. Semerjian, L. A. 2011. Quality assessment of various bottled waters marketed in Lebanon. Environ. Monit. Assess. 172:275-85. doi: 10.1007/s10661-0101333-7

2. Jeena, M. I., Deepa, P., Rahiman, K. M. M., Shanthi, R. T., and Hatha, A. A. M. 2006. Risk assessment of heterotrophic bacteria from bottled drinking water sold in Indian markets. Int. J. Hyg. Environ. Heal. 209:191-6. doi: 10.10 16/j.ijheh.2005.11.003

3. Venieri, D., Vantarakis, A., Komninou, G., and Papapetropoulou, M. 2006. Microbiological evaluation of bottled non-carbonated ('"still"') water from domestic brands in Greece. Int. J. Food Microbiol. 107:68-72. doi: 10.1016/j.jifoodmicro.2005.08.013 
4. El-salam, M. M. M. A., El-ghitany, E. M. A., and Kassem, M. M. M. 2008. Quality of bottled water brands in Egypt part ii: biological water examination. J. Egypt Public Health Assoc. 83:468-86.

5. Osei, A. S., Newman, M. J., Mingle, J. A. A., Ayeh-Kumi, P. F., and Kwasi, M. O. 2013. Microbiological quality of packaged water sold in Accra, Ghana. Food Control 31:172-5. doi: 10.1016/j.foodcont.2012.08.025

6. Akhbarizadeh, R., Dobaradaran, S., Schmidt, T. C., Nabipour, I., and Spitz, J. 2020. Worldwide bottled water occurrence of emerging contaminants: a review of the recent scientific literature. J. Hazard Mater. 392:122271. doi: 10.1016/j.jhazmat.2020.122271

7. Endocrine Disrupting Chemicals (EDCS) by Hormone Health Network. Available online at: https://www.youtube.com/watch?v=ibfAF66JzFE

8. Bisphenol A by National Institute of Environmental Health Sciences. Available online at: https://www.niehs.nih.gov/health/topics/agents/sya-bpa/index.cfm

9. Kabir, E. R., Rahman, M. S., and Rahman, I. 2015. A review on endocrine disruptors and their possible impacts on human health. Environ. Toxicol. Pharmacol. 40:241-58. doi: 10.1016/j.etap.2015.06.009

10. Laville, S., and Taylor, M. 2017. A million bottles a minute : world's plastic binge' as dangerous as climate change' contribution today. Guard 28:1-5. Available online at: https://www.theguardian.com/environment/2017/jun/28/a-million -a-minute171worlds-plastic-bottle-binge-as-dangerous-as-climate-change

SUBMITTED: 19 September 2020; ACCEPTED: 16 July 2021; PUBLISHED ONLINE: 13 August 2021.

EDITED BY: Anna Regoutz, University College London, United Kingdom

CITATION: Souza HO, Quadra GR, Costa RS, Brovini EM, Vilas-Boas JA and Fernandez MA (2021) Bacteria and Chemicals in My Bottled Water?! Front. Young Minds 9:608273. doi: 10.3389/frym.2021.608273

CONFLICT OF INTEREST: The authors declare that the research was conducted in the absence of any commercial or financial relationships that could be construed as a potential conflict of interest.

COPYRIGHT @ 2021 Souza, Quadra, Costa, Brovini, Vilas-Boas and Fernandez. This is an open-access article distributed under the terms of the Creative Commons Attribution License (CC BY). The use, distribution or reproduction in other forums is permitted, provided the original author(s) and the copyright owner(s) are credited and that the original publication in this journal is cited, in accordance with accepted academic practice. No use, distribution or reproduction is permitted which does not comply with these terms.

\section{YOUNG REVIEWER}

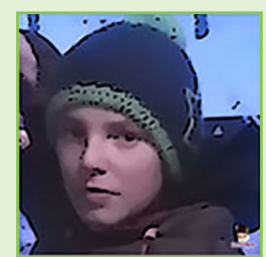

\section{FIN, AGE: 13}

In my free time I like reading books (actually I try to read books whenever there is some spare time). But I also I like skiing with friends from school or going for swimming. 

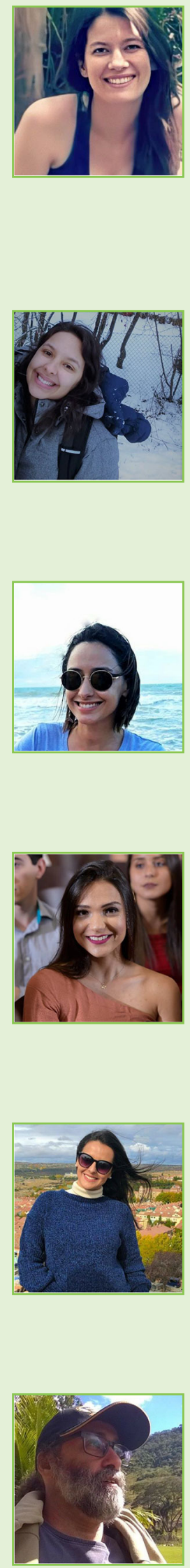

\section{AUTHORS}

\section{HELENA DE OLIVEIRA SOUZA}

I loved science classes in school, so I studied biology at the Federal University of Rio de Janeiro and received a master's degree in environmental sciences and conservation. Currently, I am a Ph.D. student in environmental sciences at the State University of Rio de Janeiro. I am studying the effects of environmental pollution on mussels that we consume. Nature brings me happiness, and this is one of my motivations to study and help take care of the environment. *helenabiologagmail.com

\section{GABRIELLE RABELO QUADRA}

I am a biologist, with a master degree in Ecology and Ph.D. in Biodiversity and Nature Conservation by the Federal University of Juiz de Fora, Brazil. I have a great interest in aquatic contamination by heavy metals and organic pollutants, such as medicines. I have also been involved in scientific communication. I believe we need to spread scientific findings outside of the academic network, especially to kids, since you are the next generation and can change the world.

\section{RAFAELA DOS SANTOS COSTA}

I am a biologist and currently a Ph.D. student in development and environment at the Federal University of Rio Grande do Norte. I have always been interested in understanding the effects of chemicals on different organisms, so I worked with environmental pollution and ecotoxicology. In recent years, I have devoted myself to studying the effects of medicines on the environment and the impact on human health.

\section{EMÍLIA MARQUES BROVINI}

I am an environmental and sanitary engineer, master of biodiversity and nature conservation at the Federal University of Juiz de Fora and current Ph.D. student of environmental engineering at the Federal University of Ouro Preto, in Brazil. I study contaminants in water, mainly pesticides. I believe that one of the purposes of science is to bring knowledge to many people, including all ages and social levels.

\section{JÉSSICA ANDRADE VILAS-BOAS}

I am a biologist, with a Ph.D. degree in Biodiversity and Nature Conservation by the Federal University of Juiz de Fora, Brazil. I am motivated to understand the effects of chemical pollutants on aquatic ecosystems, especially planktonic organisms. I have been working in the field of ecotoxicology, studying the effects of emerging contaminants in the aquatic environment and their impacts on the food web and its process and services.

\section{MARCOS ANTONIO FERNANDEZ}

I am oceanographer, with a master's in geosciences and Ph.D. in inorganic analytical chemistry. Currently, I am an associate professor of oceanography at the State University of Rio de Janeiro. My research interests are chemical oceanography and marine ecotoxicology and geochemistry. My research interests are chemical oceanography and marine ecotoxicology and geochemistry. I have been working 
mainly with contaminants present in ship paint and heavy metals. In the last years, my group developed ways to monitor the environment using animals, but without killing them, also new equipments for studies under water. I began diving by 15 , and I love marine organisms, with theirs diversity and beauty.

${ }^{\dagger}$ These authors have contributed equally to this work 